http://dx.doi.org/10.4314/jae.v15i2.1

\title{
Agricultural Extension Systems in West Africa: Adoptable Strategies for Nigeria's Agricultural Extension Reform Agenda
}

\author{
${ }^{1}$ Akinola, M.O. ${ }^{2}$ Issa, F.O. and ${ }^{1}$ Sanni, S.A. \\ ${ }^{1}$ Department of Agricultural Economics and Rural Sociology, Ahmadu Bello University (ABU), Zaria \\ ${ }^{2}$ National Agricultural Extension and Research Liaison Services (NAERLS), Ahmadu Bello University \\ $(\mathrm{ABU})$, Zaria \\ Corresponding e-mail: moluakin59@yahoo.com, Phone: 07067694919
}

\begin{abstract}
National agricultural extension and advisory systems have undergone major changes during the past two decades. These changes have been attributed to the success of the Green Revolution, commercialisation of agriculture and trade liberalization. In addition, transnational corporations develop a wide range of new technologies, which directly impact on agricultural production in developed and developing countries. As more and more production technologies become "private goods" and as an increasing percentage of farmers become commercialized producers, advisory services associated with these specialized technology transfer become progressively sophisticated to enhance its efficiency and effectiveness. This necessitates a policy reform that can accommodate the current scenario in the Nigerian quest for rural development. This paper examines the agricultural extension systems in some West African countries for possible adaptation and adoption in Nigeria's agricultural extension policy reform.
\end{abstract}

Key words: Agricultural extension systems, local development planning, reform agenda.

\section{Introduction}

Extension is the organized exchange of information and the purposive transfer of skills in order to capacitate the rural actors for continuous relevance in a commercial economy. Agricultural extension system refers to the total fabric of extension organizations' action as conduit through which educative and problem solving innovations are delivered to the appropriate target by a specialized agent (Ogunfiditimi and Ewuola, 1995). Obviously, transfer of information and skills has existed since the emergence of commercial agriculture. The practice today is different in that the process is dominated by organizations, and its scope has extended from disconnected local events to a complicated, large scale and even worldwide activity.

Agriculture is a key component of Nigerian economy, as it is in other West African countries. It currently contributes about $41 \%$ of the Nigerian GDP employing about $70 \%$ of the active population. The sector has traditionally been expected to fulfill such roles as providing food for growing population, generate foreign exchange earnings, employ part of the labour force, provide income for the farming households. However, the sector has significantly underperformed its potentials. It is characterized by food shortages, inconsistent agricultural policies and import of large quantities of rice, wheat, sugar, meat etc.

Different types of extension approaches are being practiced in various parts of the world. Each approach reflects a particular set of objectives, aims, clients and socio- 
cultural setting. Over the years, Nigeria has practiced a mix of extension approaches, starting with the colonial commodity approach that marked the beginning of scientific agriculture in Nigeria, and currently with Training and Visit Extension System, modified into the Unified Agricultural Extension System (UAES). Essentially, the national agricultural extension system has evolved from a rudimentary export focused service to a professional one.

Few extension systems can be classified as pursuing exclusively one approach, but most represent a blend of strategies within an overall framework of approaches to extension in Nigeria. Generally, these systems are top-down and supply-driven, with little or no participation by the clientele. This has led to rejection of technologies and the consequent food insecurity in the country.

\section{Need for paradigm shift in Nigeria's agricultural research and extension system}

The environment in which agricultural research and extension operates worldwide is changing rapidly. The current top-down extension approach in Nigeria is prescriptive. It does not allow for participation of all actors to ensure relevance and foster learning. It targets only parts of the system and not integrated to deal with the holistic system. It is poorly linked with markets and policy thereby making the impact to be patchy.

Under budgetary pressure and demand from the agro-industrial sector, many national agricultural research organisations face serious financial crises. The effects of globalisation and trade liberalisation, and the need to contribute to poverty alleviation as indicated in the Millennium Development Goals (MDGs) has further aggravated the challenges for research organisations. Worldwide, research organisations increasingly pursue options for decentralisation and privatisation, as well as increased client participation in technology development. There is a need to review the ways things are done and change those things that are not working. Research Institutes are structured along disciplinary, commodity or thematic lines. This has its benefits but it at times impedes the flow of knowledge and militates against adopting integrated or holistic approaches. Although participatory research methods have been promoted in recent time, the link between participatory methods, natural resource management and market relationships are still very weak.

There is the need, therefore, for:

- a shift from knowledge generation alone as the key objective and from a focus on technology (for example to increase productivity) to development outcomes measured through improvement in natural, physical, human, social and financial capital.

- a shift from mainly reductionist analysis (understanding the parts) to systemic analysis (understanding the relationships between the parts).

- A shift from scientists working in isolation to their interaction with concerned system actors resulting in increased flow and use of knowledge held by the actors, increased innovation and increased capacity to innovate.

- A shift from research systems to innovation systems.

Thus, the challenge now is to effectively involve clients of the research system in order to generate more responsive, demand-driven, impact oriented research agenda. The first Agricultural Research Council of Nigeria (ARCN) retreat for the national 
Agricultural Research Institutes (NARIs) which held in Ilorin in 2007, adopted the concept of Integrated Agricultural Research for Development (IAR4D) as an approach for conducting research that will enable the NARls to take more holistic approach in their activities (Chikwendu, 2009). IAR4D is an action research approach for investigating and facilitating the organization of groups of stakeholders (including researchers) to innovate more effectively in response to changing agricultural and natural resources management contexts, in order to achieve developmental outcomes.

\section{Extension System in Burkina Faso - Indigenous innovation Diffusion Approach}

Indigenous innovation in agriculture refers to the process by which farmers develop new and better ways of doing things, primarily using local resources and, on their own initiative, without pressure or direct support from formal research or development agents. In this process, farmers have developed not only better farming techniques but also better ways of organizing themselves. In the Yatenga Region of Burkina Faso, local improvements on a traditional farming technique have become very widespread, largely on account of the innovativeness of farmers in developing their own forms of farmer-to-farmer extension.

The farmer-to-farmer extension (diffusion) approach developed by farmer innovators in Burkina Faso include: the "Market Day", the "Teacher-Student" approach and the "Zaï Field School".

\section{The market day approach in Burkina Faso}

This is an approach to give farmers an opportunity to share their adaptations and improvements on the traditional zaï and to promote its spread. Farmers carry out informal experiments, for example, finding the most effective ways to grow tree seedlings in the zaï, testing the residual effects of compost on cereals grown in a second season, testing combinations of organic and inorganic fertilizer in the zaï, and trying to grow different crop varieties in the zaï.

At first, these events were small, but now each market day involves people from over 100 villages. The event is held twice a year. The first market day is shortly after the harvest, and farmers bring a sample of the crop varieties (millet, sorghum, maize, cowpea) they have cultivated in their zaii. Farmers store these seeds on their farms. The second market day is held just before the wet season. From the stored seeds, farmers can select the species and varieties they would like to plant in their zaï, taking into account the improvements in growing conditions resulting from their efforts. Each market day has a specific theme. For instance, during one market day, the focus was on growing sesame. Another theme was the use of zaï for growing trees directly from seed. At each market day, there is also a display of the local tools used to dig the zaï. This allows farmers from other areas to see for themselves which tools can be used and to find out where they can buy them.

The farmers involved in the zaï markets have created an "Association of Zaï Groups for the Development of the Sahel", primarily in order to mobilize external financial or material support for spreading the zaï technology. The General Assembly of this association takes place during the market days. The external support has thus far been modest. In 1997 the Association received three motorcycles, fuel and some cement from a non-governmental organization. Before 1997, innovative farmers used 
their own motorcycle and paid for their fuel to visit villages to spread the message and encourage people to share and learn at the market days. Today, it was a great achievement in managing natural resources.

\section{The teacher-student approach in Burkina Faso}

In the village of Gourcy, very experienced farmer innovators have invested heavily in improved zaï in combination with applying compost, planting trees and protecting the naturally regenerating trees and shrubs. Individual farmers in five villages close to Gourcy were trained and visited regularly to work with them directly in their fields to show them how to manage zaï, to give the farmers advice and to exchange ideas with them.

Some of the "students" do not simply adopt the technology. They carry out their own experiments based on this original idea and develop adaptations of it. For example, some farmers felt that the zaï are excessively large and require a great deal of time and physical strength to dig. They modified the layout and dimensions of the zaï to suit their capacity. Other farmers have experimented with applying different amounts of organic materials at the time of sowing or planting in the pits. Since 1993, many farmers have been trained. Their "students" in turn, train other farmers in improved zaï techniques, at their request. These farmer-trainers are not paid for their services. Their major reward is social esteem, but this is sometimes sweetened by gifts of appreciation (chickens, kola nuts or a meal).

\section{The "Zaï" field school approach in Burkina Faso}

In the village of Somyanga in Yatenga Region, some farmers initiated the "Zaï Field School" approach. In 1992, they started training some local farmers how to make good zaï. They chose the poorest possible site, immediately next to the tarmac road linking Ouahigouya and Ouagadougou, the capital city of Burkina Faso. The soils on the site had been completely destroyed by bulldozers constructing the road. The farmers practiced the different improvements on the zaï technique, such as applying organic matter (compost or manure) and using adapted cereal varieties, and assessed the results together. They managed to achieve a millet harvest of $400 \mathrm{~kg}$ per hectare on this very poor land. All people travelling along the main road saw this immediately, because it was a year of extreme drought and many crops had failed. Also, the Minister of Agriculture saw the plot and called in a team from national television to film it.

More groups of farmers were organized into "Zail" field schools. Each group is expected to rehabilitate collectively a piece of degraded land. In this way, all participants are trained on-the-job. The yields obtained on the rehabilitated land are partly shared between the members of the Zaï Field School and partly used to buy the agricultural inputs and tools needed to experiment with zaï. The experiments conceived by the farmers include comparing the impact of compost and non-decomposed manure and testing an early-maturing variety of millet that is rare in Yatenga Region.

The farmer groups that formed the initial Zaï Field Schools have widely promoted both the improved technology and their new extension approach. They have now formed a regional union - the "Association for the Conservation of Water and Soil in Yatenga" - which involves about 50 farmer groups in five divisions (Departments) of the region. This Association has set up a site for practical learning about zaï in each 
Department. Each farmer group pays a contribution of 5000 CFA (US\$ 8) to become a member of a regional union.

The successes of the Zaï Field Schools have extended beyond the borders of Yatenga Region. Members of the Association have been visited by development workers from other parts of Burkina Faso who were interested in finding out more about the Field Schools, and members of the Association have hosted farmer groups that have come to learn from them. The trainees return home not only with new knowledge but also with some seed and/or tools to use in their own experiments with zaï.

\section{The village level participatory approach (VLPA) in Benin}

During the mid 1990s, the World Bank facilitated a project built on the "Village Level Participatory Approach" (VLPA) in 500 villages of Benin's Borgou region. The rural communities participating in the VLPA identified their own development priorities and plans, and were eager to bring them to implementation. The pilot project transferred many of the implementation responsibilities to communities to increase the pace and reduce the cost of local development activities (Moumouni, 2005).

The project had three primary aims, namely to:

(a) improve rural community capacity to "better manage their socio-economic environment;

(b) meet the Borgou's immediate needs in service delivery and productive and social investment; and

(c) test new resource mobilization and implementation arrangements, as a prelude to Benin's 1999 Decentralization Law.

The project objectives were not particularly unusual. However, two project design features set the Borgou pilot apart from similar projects. The first design feature was the conscientious incorporation of the region's strengths into project design. For example, by recruiting staff locally, the project benefited from educated people's loyalty to their home region by working with village development committees established by the government extension service, CARDER (Centre d'Action Régionale pour le Dévelopment Rurale).

The second distinguishing design feature was a flexible and decentralized project framework. Participating communities drew up local development plans, submitted funding requests for their development activities, contracted project works, and ultimately "wrote the check" to the contractors hired. Communities were willing to make heavy cash contributions (20 percent of project costs) in exchange for quick sub-project implementation, and the discretion to choose the sub-projects themselves. Clear, simple lines of authority helped management to efficiently support communities. Throughout implementation, the lean and decentralized Technical Support Unit (TSU) benefited from consistent technical and managerial support from regular Bank country office and headquarters supervision visits. The TSU also developed a strong, fruitful partnership with CARDER, the government extension service.

\section{The Benin success story}

The Borgou pilot responded to the region's pressing demand for service delivery and public and social investments faster and at lower cost than comparable initiatives. Two years after implementation, 229 communities in the Borgou had completed 296 
infrastructure projects, of consistently high quality, and made more than 30 natural resource management improvements. Over 14,000 Borgou residents had participated in capacity-building activities, from 5,638 people trained in basic literacy to the 22 women trained as midwives. Project activities significantly increased the government's service delivery capacity in the Borgou. By shifting procurement responsibilities to communities, almost all of the subproject works were contracted to local firms, providing work to 70 to 80 informal enterprises.

Beyond its tangible benefits, the Borgou project reinforced a spirit of debate and collaboration within the region. With virtually all responsibility for sub-project selection, implementation, and supervision transferred to communities, the Borgou's rural communities gained discretion over their development decisions. Reflecting on the introduction of local elections, a Bank staff close to the project commented, "The beneficiaries will never again accept that educated people make decisions on their behalf."

Similarly, quick sub-project implementation inspired local populations' confidence in the project. Once a village's funding request was approved, sub-project funds were transferred to their bank account within 15 days. On their part, communities implemented their subprojects within four months of submitting their funding requests.

Both swift sub-project implementation and the decentralized project management structure contributed to a low-cost technical support unit. Twenty percent of the Borgou project's costs went to running the TSU, compared to up to 60 percent for comparable pilot operations executed through NGOs or other intermediaries.

\section{Adoptable lessons from Benin}

Drawing from the Borgou experience, several lessons stand out in the design of highly decentralized local development projects:

1. Transfer sub-project design, implementation, and supervision responsibilities to communities to the maximum degree possible;

2. Retain a flexible project design, and clear, simple lines of management accountability;

3. Reinforce a lean technical coordination unit with consistent World Bank backing, including regular technical support mission from Bank country office resident missions, supervision from headquarters, and continued financing for successful projects;

4. Capitalize on the target zone's strengths and integrate them into project design. These strengths include capacities, such as Borgou's pre-existing village development committees, rural development expertise, and the oversight ability of the CARDER extension service.

\section{Adaptation (Modification) for adoption in Nigeria}

A highly decentralized community development project can, in the most instrumental terms, provide rural communities with public services and basic productive and social infrastructure quickly and at low cost. The Borgou project model allows communities full discretion over local development decisions, while ensuring that development activities are compatible with sectoral ministries' rural development priorities. Observers have consistently cited the transfer of responsibility to communities as the project's most important design feature. 
The reform agenda in Nigeria should be holistic in its approach. It must be integrated and multidisciplinary. Above all, it must be participatory, demand-driven and need oriented. This Benin experience can be adapted through efficient local development planning and management initiative (LDPMI). The LDPMI removes the problem of unintended beneficiaries of development which has been a menace in the Nigerian agriculture.

Non-government organizations often have more flexibility in being able to work with people in a partnership situation and thus are instrumental in empowering poor people in the society. This should be adequately encouraged. The government does not have business with agricultural business. Rather, it should provide enabling environment for proper functioning and collaboration of stakeholder via stable policy and efficient infrastructure.

\section{Conclusion}

Any sincere reform of the agricultural extension agenda in Nigeria must ensure efficient and transparent local development planning and management. This will enhance project sustainability and promote agricultural development.

\section{References}

Axinn, H. G. (1997) Challenges to agricultural extension in the twenty first century. In: Farmer-led-extension. Intermediate Technology Publication. P.13-23.

Chikwendu, D. O. (2009) Re-focusing agricultural extension research in Nigeria. Paper presented at NAERLS staff orientation training programme, NAERLS/ABU conference hall, $7^{\text {th }}$ October.

Evans, J, (1990) Public library service in Papua New Guinea: the poor get poorer. Libraries alone. An International Journal, 2(1), 1990, 21 - 28.

Evans, J. (1990) Rural libraries in Papua New Guinea: More theory than practice. Libraries alone. An international journal, 2(2), 1990, 56-67.

Evans, J. (1991) Report of the library development seminar. Port Moresby: Department of Library and Information Studies, University of Papua New Guinea.

Moumouni, M. I. (2005) Analyzing the integration of the village level participatory approach into the extension system in Benin. Conference on integrated agricultural research for development.

Nagel, U. J. (1997) Alternative approaches to organizing extension, In Swanson, B. E., R. P. Bentz \& A. J. Sofranko (Eds), Improving Agricultural Extension: A Reference Manual, FAO.

Ogunfiditimi, T. O. and Ewuola, S. O., (1995) The Synthesis of comparative Agricultural Extension Systems. Emmi Press Limited Ibadan, Nigeria. pp 87

Tossou, C. R. (1996) Les acteurs et les réformes institutionnelles: une analyse de l'expérience bénnoise en matière de professionalization. Série d'Economis et de Sociologie Rurale, № 1996-65. Abomie-Calavi: FSA/UNB.

Wijasuriya, D. E. K. and Evans, J., (1992) Public library development in Papua New Guinea. Information Development, 8(1):11-21. 